\title{
Spatial-temporal variation in coiled and straight morphotypes of Cylindrospermopsis raciborskii (Wolsz) Seenayya et Subba Raju (Cyanobacteria) ${ }^{1}$
}

\author{
Ênio Wocyli Dantas ${ }^{1,4}$, Maria do Carmo Bittencourt-Oliveira ${ }^{2}$ and Ariadne do Nascimento Moura ${ }^{3}$
}

\author{
Recebido em 9/03/2009. Aceito em 27/04/2010
}

\begin{abstract}
RESUMO - (Variação espaço-temporal dos morfotipos espiralado e reto de Cylindrospermopsis raciborskii (Wolsz) Seenayya et Subba Raju (Cyanobacteria)). O presente estudo reporta o comportamento espacial e temporal dos morfotipos reto e espiralado de C. raciborskii em um reservatório da região semi-árida do Brasil bem como os principais fatores responsáveis pela variabilidade. Dois conjuntos de amostras foram coletadas na subsuperfície e próximo ao sedimento, na região central do reservatório, em dois períodos sazonais (seco - janeiro 2005; chuvoso - junho 2005), sendo realizadas amostragens de 20 horas durante horários claros (08hs, $12 \mathrm{hs} \mathrm{e} 16 \mathrm{hs})$ e escuros $(20 \mathrm{hs}, 00 \mathrm{hs}$ e $04 \mathrm{hs})$. Medidas de parâmetros abióticos foram realizadas concomitantes as amostragens das variáveis bióticas. Dois morfotipos de C. raciborskii foram encontrados no reservatório: reto e espiralado. Não houve diferenças na densidade dos morfotipos reto e espiralado de C. raciborskii entre os diferentes horários amostrais em cada período sazonal. Diferenças verticais foram encontradas na distribuição de ambos morfotipos em ambos períodos sazonais, com maiores densidades registradas na subsuperfície. As densidades dos dois morfotipos de C. raciborskii foram maiores no período seco, com densidade do morfotipo espiralado na subsuperfície duas vezes maior que o morfotipo reto e o encontrado no período chuvoso. O sucesso ecológico do morfotipo espiralado foi devido à estratificação térmica, enquanto as condições de mistura foram determinantes no sucesso do morfotipo reto.
\end{abstract}

Palavras-chave: Cylindrospermopsis raciborskii; Semi-árido; Variação diária; Variação vertical

\begin{abstract}
Spatial-temporal variation in coiled and straight morphotypes of Cylindrospermopsis raciborskii (Wolsz) Seenayya et Subba Raju (Cyanobacteria)). This study reports the spatial and temporal behavior of straight and coiled morphotypes of C. raciborskii in a reservoir in Brazil's semiarid region as well as the main factors responsible for the variability. Two set of samples were collected from the subsurface and bottom in the central region of a reservoir in two seasonal periods (dry - January 2005; rainy - June 2005) over 20-hour sampling periods during daylight (8 am, 12 pm and 4 $\mathrm{pm})$ and dark ( $8 \mathrm{pm}, 12 \mathrm{am}$ and $4 \mathrm{am})$ hours. Measurements of abiotic parameters were determined concurrently to the sampling of biotic variables. Two C. raciborskii morphotypes were found in the reservoir: straight and coiled. There was no difference in density of the straight and coiled C. raciborskii morphotypes between the different sampling times for either season. Vertical differences were found in the distribution of both morphotypes in both seasons, with greater densities recorded at the subsurface. Densities of the two C. raciborskii morphotypes were greater in the dry season, with the density of the coiled morphotype at the surface two-fold greater than that of the straight morphotype and that found in the rainy season. The ecological success of the coiled morphotype was due to thermal stratification, whereas a mixed condition was determinant in the success of the straight morphotype.

Keywords: Cylindrospermopsis raciborskii; Semi-arid; Diel variation; Vertical variation
\end{abstract}

\section{Introduction}

The plankton genus Cylindrospermopsis Seenayya et Subba Raju was separated from Anabaenopsis Woloszynska due to the different manner of development of the heterocytes (Padisák 1997). The type species $C$. raciborskii (Wolsz) Seenayya et Subba Raju was originally described in 1913 as Anabaena raciborskii Woloszynska and is a common pantropical, bloomforming species (Komárková-Legenerová 1998).

According to traditional morphological criteria, filament shape is a taxonomic characteristic that distinguishes different species. Straight forms are identified as C. raciborskii and coiled forms are identified as C. philippinensis (Taylor) Komárek and C. catemaco Komarková-Legnerová et Tavera (KomárkováLegenerová 1998). However, it is currently believed that $C$. raciborskii alone exhibits an extensive phenotypic plasticity, with straight, sigmoid and coiled filaments that can occur simultaneously (Baker 1996; Wilson et al. 2000; BittencourtOliveira \& Molica 2003). Blooms formed predominantly by one or both morphotypes are found in nature under similar conditions (Fabbro \& Duivenvoorden 1996; Bouvy et al. 1999; Saker et al. 1999; Briand et al. 2002). The ecological conditions under which the species grows and forms blooms appear to be very diverse in tropical and temperate waters (Briand $e t$ al. 2004). Perennial populations may persist throughout the year in tropical regions (Komárkova et al. 1999), where as the occurrence of species is restricted to the summer in temperate regions (Briand et al. 2002). Due to the high akinete germination temperatures and the capacity to store phosphorus and fix nitrogen, C. raciborskii develops in layers of warm waters with low light intensity and a low concentration of nutrients (Padisák \& Reynolds 1998).

Over the last twenty years, the frequent occurrence of $C$. raciborskii has been reported in bodies of water in the centerwest (Branco \& Senna 1994; 1996), southern (Komárková et al. 1999), southeastern (Souza et al. 1998) and northeastern (Bouvy et al. 2000; 2001; Chellapa \& Costa 2003; Costa et al. 2006; Panosso et al. 2007; Chellappa et al. 2008; Dantas et al. 2008) regions of Brazil. According to BittencourtOliveira \& Molica (2003), the northeastern region of the country - more specifically the state of Pernambuco - has extensive records of the presence of C. raciborskii and is the only region with records of the coiled morphotype thus far.

\footnotetext{
1 Universidade Estadual da Paraíba, Campus V, Centro de Ciências Biológicas e Sociais Aplicadas João Pessoa, PB, Brazil

2 Universidade de São Paulo, Departamento de Ciências Biológicas, Escola Superior de Agricultura Luiz de Queiroz, SP, Brazil

3 Universidade Federal Rural de Pernambuco, Departamento de Biologia, área de Botânica, Recife, PE, Brazil

4 Autor pra correspondência: eniowocyli@yahoo.com.br
} 
The present study reports the spatial and temporal behavior of the straight and coiled morphotypes of $C$. raciborskii in a reservoir in a semi-arid region of Brazil as well as the main factors responsible for the variability.

\section{Material and methods}

The study was carried out at the Mundau Reservoir $\left(08^{\circ} 56^{\prime} 47^{\prime \prime} \mathrm{S}\right.$ and $36^{\circ} 29^{\prime} 33^{\prime \prime} \mathrm{W}$ ) in the state of Pernambuco (northeastern Brazil), which is located $716 \mathrm{~m}$ above sea level. The reservoir is intended for the public water supply and was constructed to accumulate $1,968,600 \mathrm{~m}^{3}$. It currently receives part of the domestic drainage from the city of Garanhuns (Moura et al. 2007b).

Two set of samples were collected from the subsurface and bottom $(8 \mathrm{~m})$ in the central region of the reservoir in two periods: the dry season (January 2005) and the rainy season (June 2005). Sampling was carried out over 20-hour periods during daylight ( $8 \mathrm{am}, 12 \mathrm{pm}$ and $4 \mathrm{pm})$ and dark ( $8 \mathrm{pm}, 12 \mathrm{am}$ and $4 \mathrm{am}$ ) hours. One hundred $\mathrm{mL}$ aliquots of water were collected and preserved in an acetic Lugol's solution for the identification and determination of phytoplankton density (ind. $\mathrm{L}^{-1}$ ) using an inverted microscope and following the Utermöhl method (Utermöhl 1958). Trichomes of C. raciborskii were photographed using a light microscope (Nikon E200, Melville, NY, 120 USA) equipped with a video camera system (Samsung SCC833, Tokyo, Japan) and employing the Imagelab software program (Softium, Brazil). Data on density were used to determine the dominance of $C$. raciborskii, based on the criteria described by Lobo \& Leighton (1986). The species was considered abundant when the value calculated was greater than the mean value of the community and dominant when this value surpassed $50 \%$ of the total phytoplankton density.

Concurrently to the samplings of algae, the following abiotic variables were determined in situ: water temperature and dissolved oxygen using an oximeter (Schott Glaswerke Mainz, handylab OX1); electrical conductivity using a conductivimeter (Schott Glaswerke Mainz, handylab LF1); turbidity using a turbidimeter (Hanna Instruments, HI 93703); and $\mathrm{pH}$ using a potentiometer (Digimed, DMPH-2). Water transparency was determined using a Secchi disc $\left(25 \mathrm{~cm}\right.$ in diameter) and underwater light $\left(\mu \mathrm{mol} \cdot \mathrm{m}^{-2} \cdot \mathrm{s}^{-1}\right)$ was determined using a light sensor (LICOR mod. 250).

Water from two depths was collected using van Dorn bottle and aliquots were placed in $300 \mathrm{~mL}$ polyethylene flasks for the analysis of dissolved and total nutrients. The determination of concentrations of total nitrogen $(\mu \mathrm{mol}$. TN.L-1 $)$, nitrite $\left(\mu \mathrm{mol} . \mathrm{N}-\mathrm{NO}_{2} \cdot \mathrm{L}^{-1}\right)$ and nitrate $\left(\mu \mathrm{mol} . \mathrm{N}-\mathrm{NO}_{3} \cdot \mathrm{L}^{-1}\right)$ followed the procedures described in Valderrama (1981), Mackereth et al. (1978) and Golterman et al. (1971), respectively. Total phosphorus ( $\mu$ mol.TP.L $\left.{ }^{-1}\right)$ and total dissolved phosphorus ( $\mu$ mol.TDP.L $\left.L^{-1}\right)$ were determined following Valderrama (1981). Orthophosphate $\left(\mu\right.$ mol.P-PO $\left.{ }_{4} \cdot \mathrm{L}^{-1}\right)$ was determined following Strickland \& Parsons (1965).

For the trophic characterization of the ecosystems, we employed the Carlson Trophic State Index, adapted by Toledo Jr. et al. (1983) for tropical regions. Calculations were based on total phosphorus content, for which ultra-oligotrophic $(\leq 20)$, oligotrophic $(21-40)$, mesotrophic $(41-50)$, eutrophic $(51-60)$ and hypertrophic $(\geq 61)$ conditions were then determined (Kratzer \& Brezonik 1981).

Analysis of variance (ANOVA) was used with a 5\% level of significance to determine the degree of temporal variation (time of day and season) and spatial variation between depths. Pearson's correlation analysis (r) was performed for the straight and coiled morphotypes in relation to environmental variables using the Statistica 2004 software program (StatSoft, Inc., Tulsa, OK, USA).

\section{Results}

Both straight and coiled morphotypes of $C$. raciborskii were found in the Mundaú reservoir. Few trichomes had heterocytes and akinetes (Fig. 1a-b).

Total density of the other plankton algae (without $C$. raciborskii) ranged from $14.4 \times 10^{6}$ at $8 \mathrm{pm}$ on the bottom in the rainy season to $68.7 \times 10^{6}$ ind. $\mathrm{L}^{-1}$ at 8 am at the subsurface in the dry season. C. raciborskii density ranged from $13.1 \mathrm{x}$

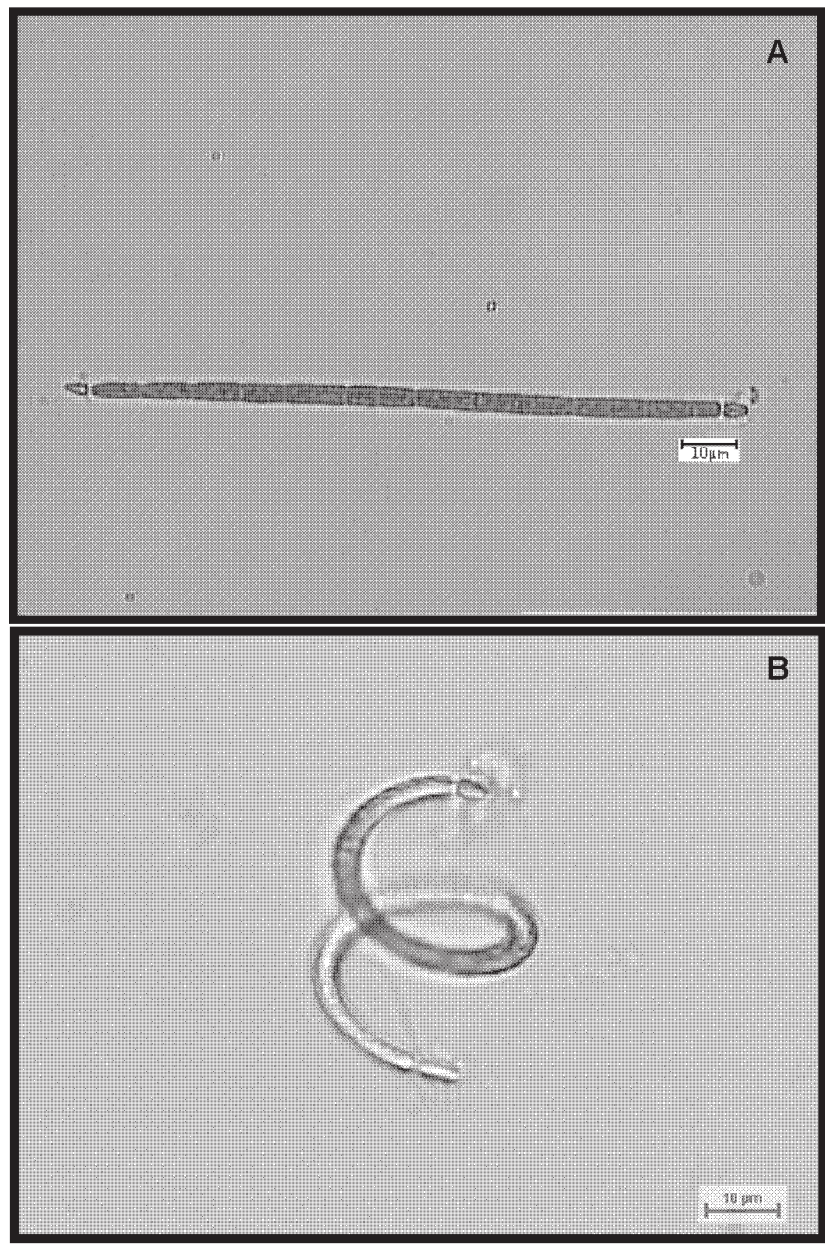

Figure 1. Morphological features of Cylindrospermopsis raciborskii. (a) Straight morphotype, with hetrocytes in the terminal position of the trichome occurring at both ends; (b) Coiled morphotype, with heterocytes in the terminal position of the trichome occurring at both ends.

$10^{6}$ at $4 \mathrm{pm}$ at the bottom in the rainy season to $113.6 \times 10^{6}$ ind. $\mathrm{L}^{-1}$ at 8 am at the subsurface in the dry season, thereby demonstrating the considerable participation of the species in the phytoplankton community. The density of $C$. raciborskii was greater than the other algae at the subsurface at all times of the day and in both seasons, demonstrating dominance. Despite the high density of the species at the bottom, it was less than the density of other algae in both seasons at nearly all times of day, except at 12 am in the rainy season, when the density of the species was slightly greater. At the bottom, $C$. raciborskii was classified as abundant at all times of the day, except at $12 \mathrm{am}$ in the rainy season, when it was classified as dominant (Fig. 2).

Figure 3a-d displays the variation in straight and coiled morphotypes at the different sampling times in both seasons. There were no significant differences in density between morphotypes. There was no significant difference in the density of the coiled morphotype at different times of the day in the dry season $(\mathrm{F}=1.057, p>0.05)$ or the rainy season $(\mathrm{F}=0.305, \mathrm{p}>0.05)$. For the straight morphotype, these values were $\mathrm{F}=0.904(p>0.05)$ and $\mathrm{F}=0.253(p>0.05)$ for the dry and rainy season, respectively. 


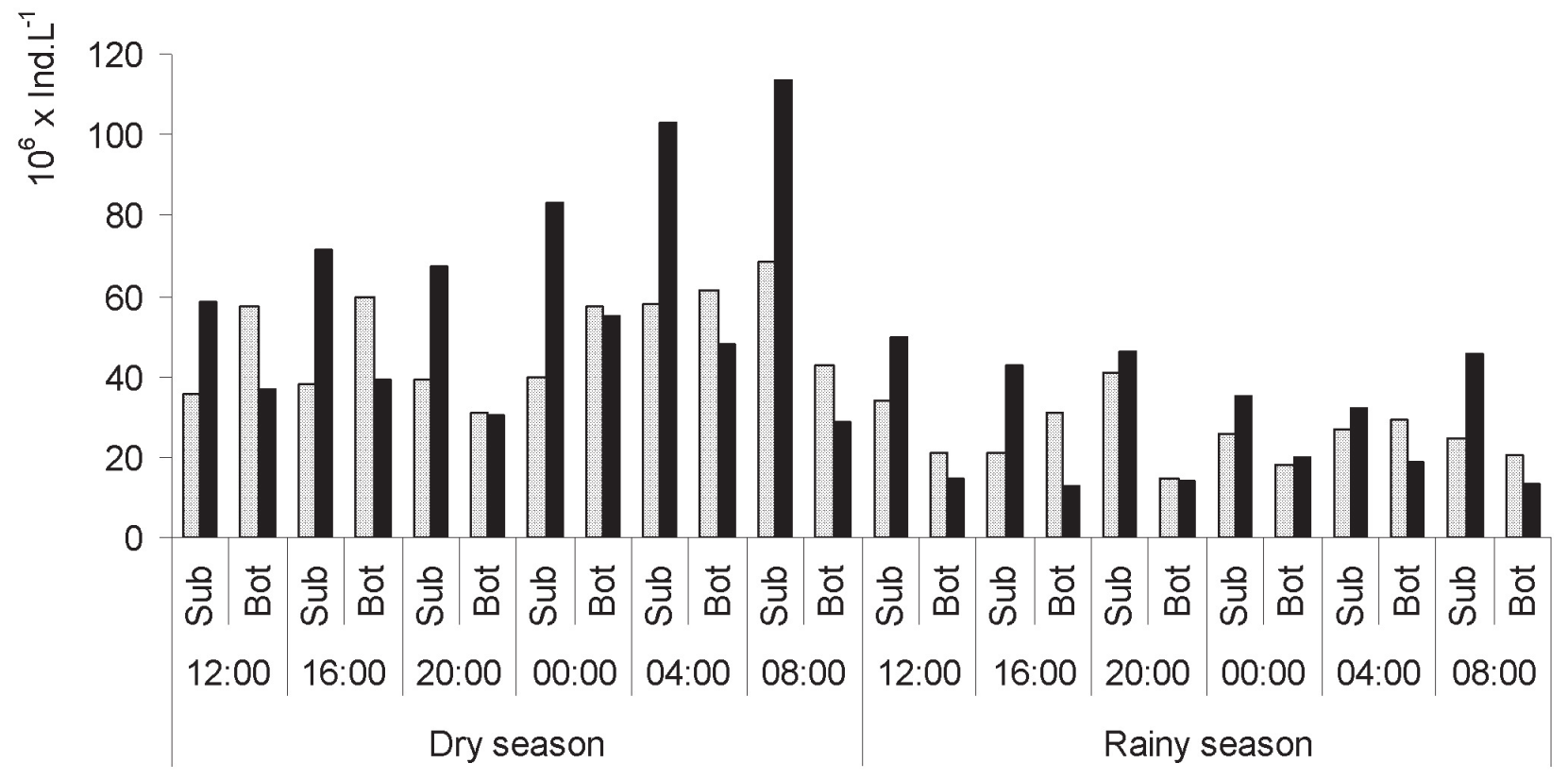

$\square$ Others plankton algae $\square$ C. raciborskii

Figure 2. Total density of phytoplankton (without C. raciborskii) and density of C. raciborskii at subsurface and bottom of Mundaú reservoir at different times of the day in the dry and rainy seasons. Sub: subsurface; Bot: Bottom.

Vertical differences were found in the distribution of both morphotypes in both seasonal periods, with greater densities recorded at the subsurface (Fig. 3a-d). Density of the two $C$. raciborskii morphotypes was higher in the dry season, with the density of the coiled morphotype at the surface two-fold greater than that of the straight morphotype in this season. In the rainy season, there was an accentuated reduction in the density of the coiled morphotype, with lower values in comparison to the straight morphotype (Fig. 3a-d).

Figures 4a-1 and 5a-1 displays the physico-chemical variation between times of the day and depths in the dry and rainy seasons. No significant differences $(p>0.05)$ were found in the abiotic variables between sampling times in the dry season. In the rainy season, significant differences $(p<$ 0.05 ) occurred in water temperature, $\mathrm{pH}$ and total dissolved phosphorus.

Vertical differences $(p<0.05)$ were found in the dry season for temperature, dissolved oxygen, $\mathrm{pH}$, turbidity, total nitrogen, total phosphorus and total dissolved phosphorus. In the rainy season, all variables (except total phosphorus) exhibited vertical differences.

There were significant differences between seasons ( $p$ $<0.01)$ regarding water temperature, dissolved oxygen, electrical conductivity, turbidity, $\mathrm{pH}$, total nitrogen, nitrate, nitrite, total dissolved phosphorus and orthophosphate. There were no statistically significant differences between seasons $(p>0.05)$ regarding light intensity and total phosphorus, although higher light intensity values were observed at the subsurface in the dry season.
Based on physical-chemical characteristics, Mundaú reservoir is classified as a hypertrophic tropical system. The correlation analysis with the pooled data of both seasons revealed that the straight and coiled morphotypes of $C$. raciborskii had a positive correlation with water temperature and $\mathrm{pH}$ as well as a negative correlation with turbidity, total nitrogen, nitrate, nitrite and total phosphorus. The coiled morphotype was also positively correlated with light intensity and orthophosphate as well as negatively correlated with electrical conductivity (Tab. 1).

In the dry season, significant correlations were found between the $C$. raciborskii morphotypes and environmental variables in the reservoir. The straight morphotype had a positive correlation with turbidity and $\mathrm{pH}$ and a negative correlation with total phosphorus, whereas the coiled morphotype had a positive correlation with water temperature, turbidity and $\mathrm{pH}$ and a negative correlation with total nitrogen, total phosphorus and total dissolved phosphorus (Tab. 1).

In the rainy season, significant correlations were also found between the C. raciborskii morphotypes and environmental variables in the reservoir. Both morphotypes had positive correlations with light intensity, water temperature, dissolved oxygen, electrical conductivity and $\mathrm{pH}$, whereas the two morphotypes had negative correlations with turbidity, total nitrogen, nitrate, nitrite and total phosphorus (Tab. 1).

\section{Discussion}

C. raciborskii density was high in both seasons. This occurrence was associated to high temperatures, which were always above $22^{\circ} \mathrm{C}$ in the reservoir, as well as alkaline 

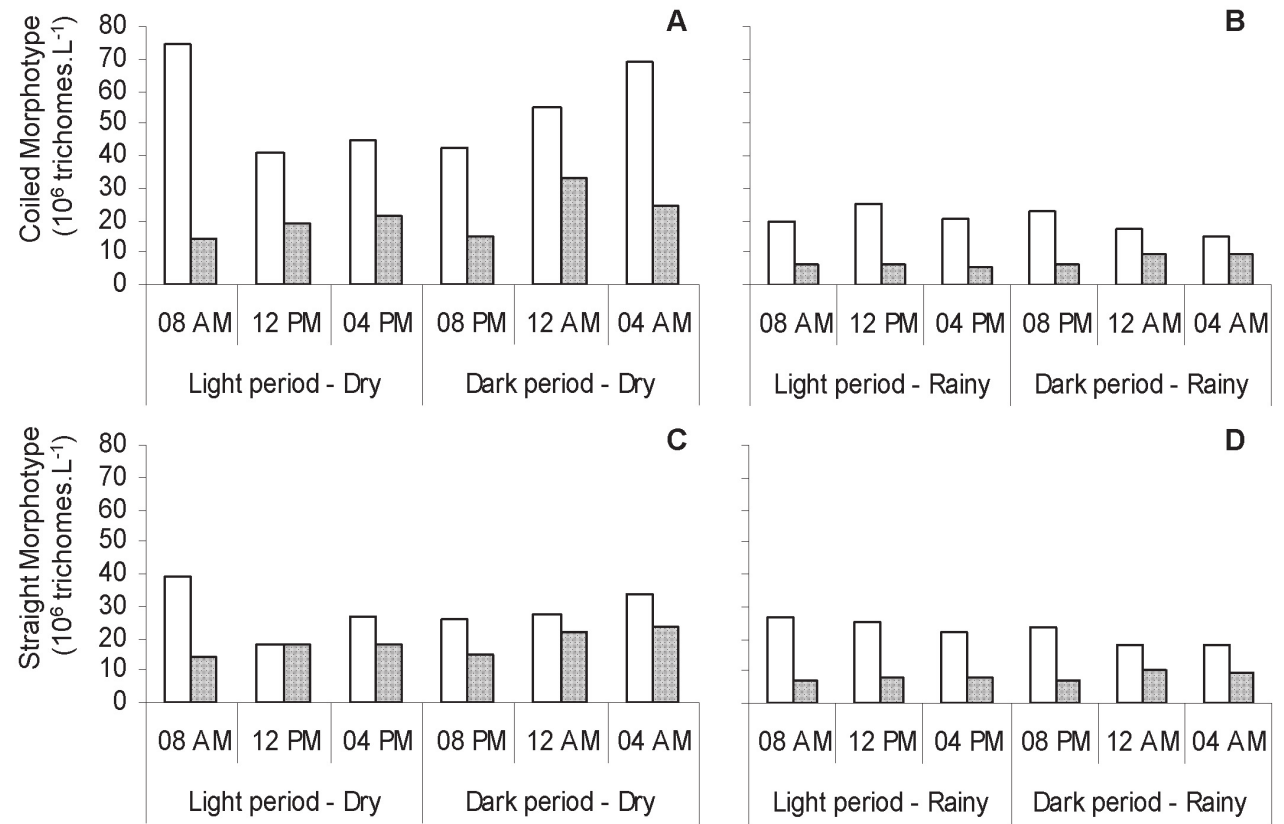

$\square$ Subsurface $\square$ Bottom

Figure 3

Figure 3. Variation in C. raciborskii density at the subsurface and bottom at different times of the day in the Mundaú reservoir (PE, Brazil). A. Coiled morphotype during light and dark hours in the dry season; B. Coiled morphotype light and dark hours in the rainy season; C. Straight morphotype light and dark hours in the dry season; D. Straight morphotype light and dark hours in the rainy season.
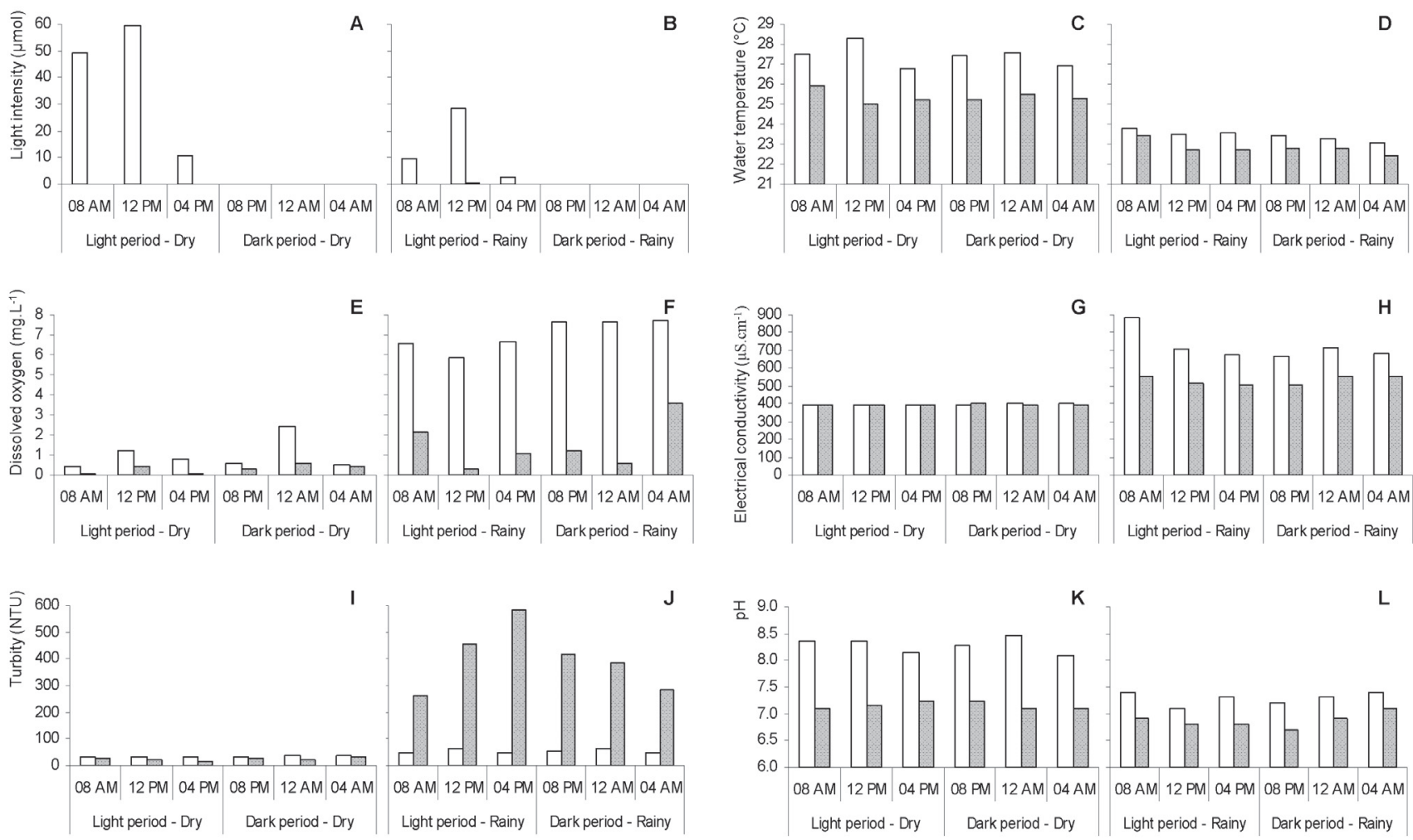

$\square$ Subsurface $\square$ Bottom

Figure 4. Physiochemical variation at subsurface and bottom in the Mundaú reservoir in the dry and rainy seasons. a. Light intensity in the dry season; b. Light intensity in the rainy season; c. Water temperature in the dry season; d. Water temperature in the rainy season; e. Dissolved oxygen in the dry season; f. Dissolved oxygen in the rainy season; g. Electrical conductivity in the dry season; h. Electrical conductivity in the rainy season; i. Turbidity in the dry season; j. Turbidity in the rainy season; $\mathrm{k} . \mathrm{pH}$ in the dry season; $1 . \mathrm{pH}$ in the rainy season. 

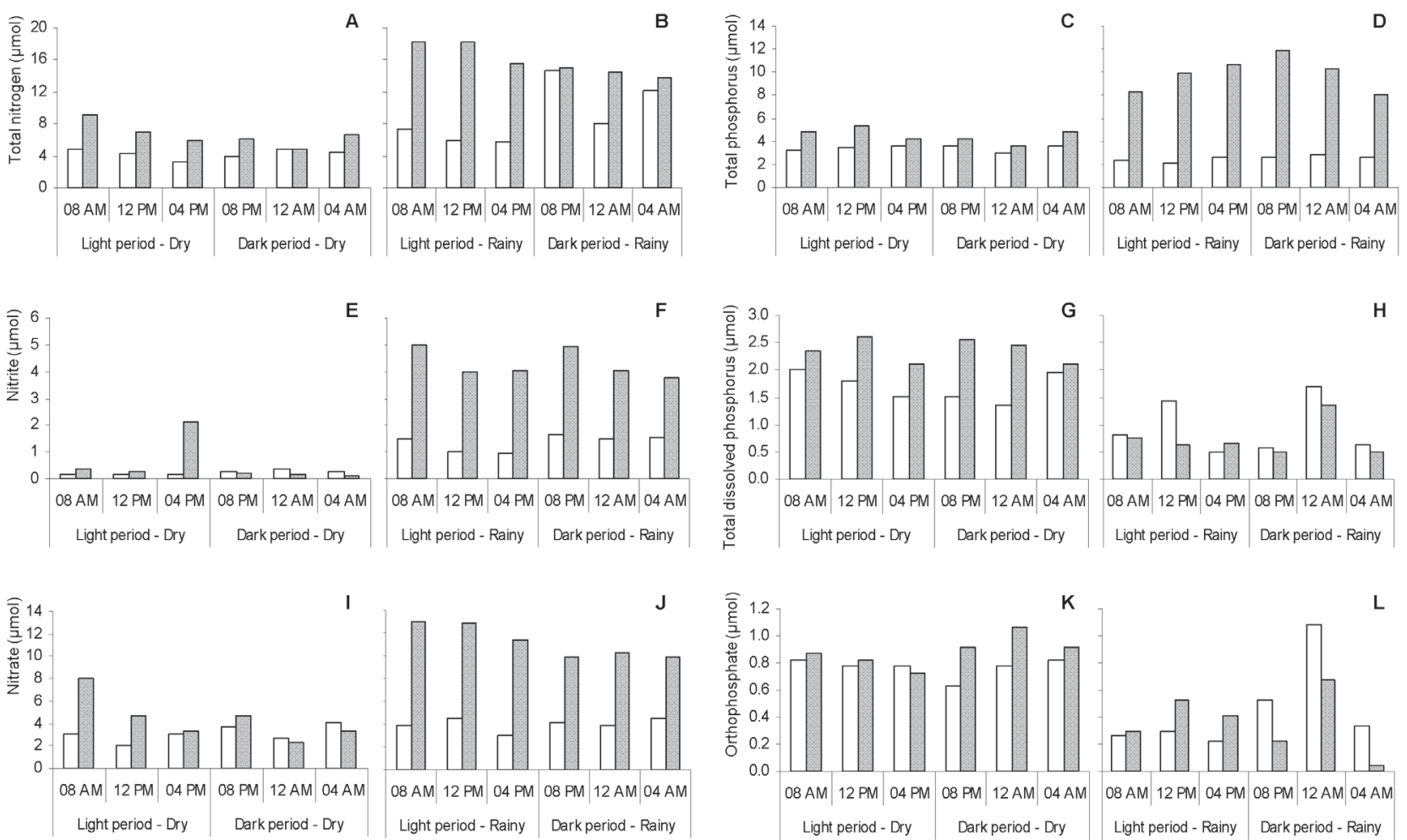

Figure 5

口 Subsurface $\square$ Bottom

Figure 5. Physiochemical variation at subsurface and bottom in the Mundaú reservoir in the dry and rainy seasons. a. Total nitrogen in the dry season; b. Total nitrogen in the rainy season; c. Nitrate in the dry season; $d$. Nitrate in the rainy season; e. Nitrite in the dry season; f. Nitrite in the rainy season; g. Total phosphorus in the dry season; h. Total phosphorus in the rainy season; i. Total dissolved phosphorus in the dry season; j. Total dissolved phosphorus in the rainy season; k. Orthophosphate in the dry season; 1 . Orthophosphate in the rainy season.

$\mathrm{pH}$ and the hypertrophy of the system. The environmental conditions in the Mundaú reservoir are the same reported by other researchers as favorable to blooms of this species in other ecosystems in northeastern Brazil (Bouvy et al. 2000; Chellapa \& Costa 2003; Moura et al. 2007b; Chellappa et al. 2008; Von Sperling et al. 2008). Regardless of geographic location, these populations grow and form blooms only in warm waters with temperatures above $25^{\circ} \mathrm{C}$ (Padisák 1997; Saker \& Griffiths 2001) or in hypolimnetic waters with temperatures above $23^{\circ} \mathrm{C}$ (McGregor \& Fabbro 2000).

The greatest densities of two morphotypes of $C$. raciborskii in the dry season occurred at a mean temperature of $27.4^{\circ} \mathrm{C}$. Blooms recorded in the rainy season occurred at a mean temperature of $23.5^{\circ} \mathrm{C}$, which is a reflection of the mixture condition evidenced for the period, as stated by Moura et al. (2007a). Although thermal stratification influences the occurrence of high densities of $C$. raciborskii (Bouvy et al. 2000), de-stratification or a mixture condition can be an advantage to the species in tropical environments, especially considering the fact that this taxon is pre-adapted to low-light conditions (Shafik et al. 2001).

The population dynamics of $C$. raciborskii is dependent upon the presence of particular environmental conditions, which mainly include warm, stratified surface waters, low light and alkaline pH (Padisák 1997; McGregor \& Fabbro 2000;
Briand et al. 2004). Although C. raciborskii is less dependent upon nutrients than other cyanobacteria (Bouvy et al. 2000), an affinity for phosphorus is suggested (Isvánovics et al. 2000).

The role of nutrients in the development of $C$. raciborskii was not relevant. The greatest densities occurred in the period with less nitrogen content, which was limited throughout the entire study. Furthermore, in environments with reactive soluble phosphorus concentrations greater than $10 \mu \mathrm{g} . \mathrm{L}^{-1}$, the development of cyanobacteria is regulated by physical factors (Saker et al. 1999). C. raciborskii blooms do not depend upon the presence of nitrogen, as the species is able to fix atmospheric nitrogen through heterocytes. This appears contradictory, as few trichomes with heterocytes were found in the reservoir. However, studies have found that $C$. raciborskii appears not to be dependent upon the fixation of nitrogen (e.g. Griffiths \& Saker 2003) and that few heterocytes are found even at lower concentrations of this element (Pressing et al. 1996). This is especially due to its greater affinity for ammonium than other nitrogenated elements (Bouvy et al. 1999; Briand et al. 2002).

Concerning the different morphotypes of C. raciborskii, there was no evident variation in density throughout the daily sampling times. The stable behavior of the morphotypes occurred due to environmental stability at the different times of the day in each season. This finding corroborates that 
Table 1. Correlation values of environmental variables and densities of different $C$. raciborskii morphotypes in the Mundaú reservoir between seasonal periods. Values in bold type $=$ significant differences.

\begin{tabular}{|c|c|c|c|c|c|c|c|c|c|c|c|c|}
\hline & \multicolumn{4}{|c|}{ Dry season } & \multicolumn{4}{|c|}{ Rainy season } & \multicolumn{4}{|c|}{ Two seasonal periods } \\
\hline & \multicolumn{2}{|c|}{ straight } & \multicolumn{2}{|c|}{ coiled } & \multicolumn{2}{|c|}{ straight } & \multicolumn{2}{|c|}{ coiled } & \multicolumn{2}{|c|}{ straight } & \multicolumn{2}{|c|}{ coiled } \\
\hline & $r$ & $p$ & $r$ & $p$ & $r$ & $p$ & $r$ & $p$ & $r$ & $p$ & $r$ & $p$ \\
\hline Underwater light $\left(\mu \mathrm{mol} \cdot \mathrm{m}^{-2} \cdot \mathrm{s}^{-1}\right)$ & 0.277 & 0.383 & 0.432 & 0.161 & 0.577 & 0.049 & 0.592 & 0.042 & 0.385 & 0.063 & 0.473 & 0.019 \\
\hline Dissolved oxygen (mg.L-1) & 0.228 & 0.476 & 0.406 & 0.190 & 0.854 & 0.000 & 0.851 & 0.000 & 0.660 & 0.000 & 0.828 & 0.000 \\
\hline Water temperature $\left({ }^{\circ} \mathrm{C}\right)$ & 0.528 & 0.077 & 0.741 & 0.006 & 0.797 & 0.002 & 0.750 & 0.005 & 0.088 & 0.683 & -0.206 & 0.333 \\
\hline Electrical conductivity $(\mu \mathrm{S} . \mathrm{cm}-1)$ & 0.442 & 0.150 & 0.501 & 0.097 & 0.907 & 0.000 & 0.799 & 0.002 & -0.099 & 0.643 & -0.410 & 0.047 \\
\hline Turbity (NTU) & 0.597 & 0.040 & 0.700 & 0.011 & -0.867 & 0.000 & -0.871 & 0.000 & -0.714 & 0.000 & -0.543 & 0.006 \\
\hline $\mathrm{pH}$ & 0.652 & 0.022 & 0.820 & 0.001 & 0.815 & 0.001 & 0.750 & 0.005 & 0.749 & 0.000 & 0.884 & 0.000 \\
\hline Total nitrogen $(\mu \mathrm{mol})$ & -0.561 & 0.058 & -0.661 & 0.019 & -0.818 & 0.001 & -0.800 & 0.002 & -0.765 & 0.000 & -0.706 & 0.000 \\
\hline Nitrate $(\mu \mathrm{mol})$ & -0.415 & 0.179 & -0.473 & 0.120 & -0.922 & 0.000 & -0.915 & 0.000 & -0.792 & 0.000 & -0.643 & 0.001 \\
\hline Nitrite $(\mu \mathrm{mol})$ & -0.252 & 0.429 & -0.254 & 0.425 & -0.938 & 0.000 & -0.930 & 0.000 & -0.770 & 0.000 & -0.659 & 0.000 \\
\hline Total phosphorus $(\mu \mathrm{mol})$ & -0.603 & 0.038 & -0.764 & 0.004 & -0.924 & 0.000 & -0.913 & 0.000 & -0.766 & 0.000 & -0.545 & 0.006 \\
\hline Total dissolved phosphorus $(\mu \mathrm{mol})$ & -0.483 & 0.112 & -0.591 & 0.043 & 0.242 & 0.449 & 0.295 & 0.351 & 0.354 & 0.089 & 0.388 & 0.061 \\
\hline Orthophosphate $(\mu \mathrm{mol})$ & -0.169 & 0.600 & -0.259 & 0.416 & 0.035 & 0.914 & 0.084 & 0.794 & 0.350 & 0.093 & 0.430 & 0.036 \\
\hline
\end{tabular}

described by McGregor \& Fabbro (2000), who found that tropical reservoirs with the same characteristics observed in the present study are propitious to the development of large C. racibosrskii populations. The stability in the Mundaú reservoir was therefore evidenced by the limited variation in density of the two morphotypes throughout the different times of the day.

The behavior of the straight and coiled morphotypes exhibited seasonal differences. Vertical differences were found in the distribution of both morphotypes in both seasonal periods, with greater densities recorded at the subsurface. In the dry season, the density of the coiled morphotype was much higher than that of the straight morphotype. This certainly occurred due to the higher temperature in this season and the evident vertical variation in this variable. In the rainy season, there was an accentuated reduction in the density of the coiled morphotype, with values below those for the density of the straight morphotype. This reduction was certainly due to the homogeneity of the water column and the reduction in light intensity values in this season.

Little is known regarding the ecological advantages and disadvantages of the different morphotypes of a species. Specifically for $C$. raciborskii, environmental factors that contribute toward the formation of the two morphotypes are related to resistance to sinking (Padisák et al. 2003) and predation (Fabbro \& Duivenvoorden 1996). The coiled form has less resistance to sinking in comparison to the straight form (Padisák et al. 2003), whereas Fabbro \& Duivenvoorden (1996) found that the coiled form is less susceptible to predation than the straight form. According to Padisák et al. (2003), water density is one of the most important factors related to resistance to sinking and is influenced by thermal gradients. Such gradients may favor forms that are less resistant to sinking, such as the coiled filaments of $C$. raciborskii. The thermal stratification of the water in the Mundaú reservoir (Moura et al. 2007b; Dantas et al. 2008) certainly contributed toward the greater density of the coiled morphtype in the dry season in comparison to the rainy season, when the reservoir was de-stratified.

Among zooplankton organisms, rotifers are only dominant during and immediately following a C. raciborskii bloom (Griffiths \& Saker 2003). In Brazil, rotifers and copepods may actually be able to cut up and shorten filaments into edible sizes for other zooplankton. Rotifer and copepod densities increased with C. raciborskii blooms and decreased following the bloom, whereas cladoceran density increased after blooms. Analyzing the zooplankton community in the Mandaú reservoir during the same period in which the present study was carried out, Dantas et al. (in press) found that Rotifera was the dominant group throughout the study, followed by Copepoda and a small contribution from Cladocera. This reveals that predation is not a determinant factor in the density of $C$. raciborskii morphotypes, as there were not enough predators for this species in the reservoir during the study period.

\section{Conclusion}

The difference in behavior of the straight and coiled $C$. raciborskii morphotypes between seasons was due to the significant environmental differences between the two periods. Water temperature, $\mathrm{pH}$ and phosphorus concentration were greater in the dry period, whereas electrical conductivity, turbidity and nitrogen concentrations were greater in the rainy season. These variables explain the greater densities of these morphotypes in the dry season, whereas thermal behavior explains the differences in density between morphotypes. The ecological success of the coiled morphotype was due to thermal stratification, whereas the mixture condition was determinant in the success of the straight morphotype. 


\section{Acknowledgments}

This study was supported by grants from $\mathrm{CNPq}$ (Brazilian Council for Research and Development) to ANM: 300612/2005-2.

\section{References}

Baker P. D. 1996. Occurrence of Cylindrospermopsis in South-Eastern Australia. In: Cylindrospermopsis - A New Toxic Algal Bloom Challenge for Australia. Brisbane, Agricultural and Resource Management Council of Australia and New Zealand.

Bittencourt-Oliveira, M.C. \& Molica, R. 2003. Cianobactéria Invasora: aspectos moleculares e toxicológicos de Cylindrospermopsis raciborskii no Brasil. Biotecnologia 30: 82-90.

Bouvy, M.; Molica, R.; Oliveira, S.; Marinho, M. \& Becker, B. 1999. Dynamics of a toxic cyanobacterial bloom (Cylindrospermopsis raciborskii) in a shallow reservoir in the semi-arid region of northeast Brazil. Aquatic Microbial Ecology 20: 285-297.

Bouvy, M.; Falcão, D.; Marinho, M.; Pagano, M.\& Moura, A. 2000. Occurrence of Cylindrospermopsis (Cyanobacteria) in 39 brazilian tropical reservoirs during the 1998 drought. Aquatic Microbial Ecology 23: 13-27.

Bouvy, M.; Pagano, M. \& Trusselier, M. 2001. Effects of a cyanobacterial bloom (Cylindrospermopsis raciborskii) on bacteria and zooplankton communities in Ingazeira reservoir (northeast Brazil). Aquatic Microbial Ecology 25: 215-227.

Branco, C.W.C. \& Senna, P.A.C. 1994. Factors influencing the development of Cylindrospermopsis raciborskii and Microcystis aeruginosa in Paranoá Reservoir, Brasília, Brazil. Algological Studies 75: 85-96.

Branco, C.W.C. \& Senna, P.A.C. 1996. Phytoplankton composition, community structure and seasonal changes in a tropical reservoir (Paranoá Reservoir, Brazil). Algological Studies 81: 69-84.

Briand, J.F.; Robillot, C.; Quiblier-Lloberas, C.; Humbert, J.F. \& Coute, A. 2002. Environmental context of Cylindrospermopsis raciborskii (cyanobacteria) blooms in a shallow pond in France. Water Research 36: 3183-3192.

Briand, J.F.; Leboulanger, C.; Humbert, J.-F.; Bernard, C. \& Dufour, P. 2004. Cylindrospermopsis raciborskii (Cyanobacteria) invasion at mid-latitudes: selection, wide physiological tolerance, or global warming? Journal of Phycology 40: 231-238.

Chellappa, N.T. \& Costa, M.A.M. 2003. Dominant and co-existing species of Cyanobacteria from a Eutrophicated reservoir of Rio Grande do Norte State, Brazil. Acta Oecologica 24: 3-10.

Chellappa, N.T.; Chellappa, S.L.\& Chellappa, S. 2008. Harmful Phytoplankton Blooms and Fish Mortality in aeutrophicated reservoir of Northeast Brazil. Brazilian Archives of Biology and Technology 51: 833-841.

Costa, I.A.S.; Azevedo, S.M.F.O.; Senna, P.A.C.; Bernardo, R.R.; Costa, S.M. \& Chellappa, N.T. 2006. Occurrence of toxin-producing cyanobacteria blooms in a brazilian semiarid reservoir. Brazilian Journal of Biology 66: 211-219.

Dantas, E.W.; Moura, A.N.; Bittencourt-Oliveira, M.C.; Arruda Neto, J.D.T. \& Cavalcanti, A.D.C. 2008. Temporal variation of the phytoplankton community at short sampling intervals in the Mundaú reservoir, Northeastern Brazil. Acta Botanica Brasilica 22: 970-982.

Dantas, E.W.; Almeida, V.L.S.; Barbosa, J.E.L.; Bittencourt-Oliveira, M.C. \& Moura, A.N. in press. Efeitos das variáveis abióticas e do fitoplâncton sobre a comunidade zooplanctônica em um reservatório do Nordeste brasileiro. Iheringia. Série Zoologia 99: 132-141.

Fabbro, L.D. \& Duivenvoorden, L.J. 1996. Profile of a bloom of the cyanobacterium Cylindrospermopsis raciborskii (Woloszynska) Seenaya and Subba Raju in the Fitzroy River in tropical central Queensland. Marine and Freshwater Research 47: 685-94.

Golterman, H.; Clymo, R.S. \& Ohnstad, M.A.M. 1971. Methods for physical and chemical analysis of freshwaters, Oxford, Blackwell Scientific Publications.

Griffiths, D.J. \& Saker, M.L. 2003. The Palm island mystery disease 20 years on a review of research on cyanotoxin cylindrospermopsin. Environmental Toxicology 18: 78-93.

Isvánovics, V.; Shafik, H.M.; Présing, M. \& Juhos, S. 2000. Growth and phosphate uptake kinetics of the cyanobacterium, Cylindrospermopsis raciborskii (Cyanophyceae) in throughflow cultures. Freshwater Biology 43: $257-275$.

Komárková-Legenerová, J. 1998. The tropical planktonic genus Cylindrospermopsis (Cyanophytes, Cyanobacteria). In IV Congresso Latino Americano de Ficologia, Brazil. (M.T.P. Azevedo, coord.). Soc. Ficol. América Latina e Caribe, Caribe, Caxambu. pp. 327-340.
Komárková, J.; Laudares-Silva, R. \& Senna, P.A.C. 1999. Extreme morphology of Cylindrospermopsis raciborskii (Nostocales, Cyanobacteria) in the Lagoa do Peri, a freshwater coastal lagoon, Santa Catarina, Brazil. Algological Studies 94: 207-222.

Kratzer, C.R. \& Brezonik, P.L. 1981. A Carlson type trophic state index for nitrogen in Florida lakes. Water Resources Bulletin 17: 713-714.

Lobo, E. \& Leighton, G. 1986. Estructuras comunitarias de las fitocenosis planctonicas de los sistemas de desembocaduras de rios y esteros de la zona central de Chile. Revista de Biologia Marinha 22: 1-29.

Mackereth, J.J.H.; Heron, J. \& Talling, J.F. 1978. Water analysis: some revised methods for limnologists. Kendall, Titus Wilson \& Son, Freshwater Biological Association. Scientific Publication.

Mc Gregor, G.B. \& Fabbro, L.D. 2000. Dominance of Cylindrospermopsis raciborskii (Nostocales, Cyanoprokaryota) in Queensland tropical and subtropical reservoirs: Implications for monitoring and management. Lakes \& Reservoirs Research and Management 5: 195-205.

Moura,A.N.; Bittencourt-Oliveira, M.C; Dantas, E.W. \& Arruda Neto, J.D.T. 2007a. Phytoplanktonic Associations: A Tool to Understand Dominance Events in a Tropical Brazilian Reservoir. Acta Botanica Brasilica 21: 641-648.

Moura, A.N.; Dantas, E.W. \& Bittencourt-Oliveira, M.C. 2007b. Structure of the Phytoplankton in a Water Supply System in the State of Pernambuco Brazil. Brazilian Archives of Biology and Technology 50: 645-654.

Padisák, J. 1997. Cylindrospermopsis raciborskii (Woloszynska) Seenayya et Subba Raju, an expanding, highly adaptative cyanobacterium: worldwide distribution and review of its ecology. Archiv fuer Hydrobiologie 107: 563-593.

Padisák, J. \& Reynolds, C.S. 1998. Selection of phytoplankton associations in Lake Balaton, Hungary, in response to eutrophication and restoration measures, with special reference to the cyanoprokaryotes. Hydrobiologia 384: 41-53.

Padisák, J.; Bórics, G.; Feher, G.; Grigorszky, I.; Olda, I.; Schmidt, A. \& Zambone-Doma, Z. 2003. Dominant species, functional assemblages and frequency of equilibrium phases in late summer phytoplankton assemblages in Hungarian small shallow lakes. Hydrobiologia 502: 157-168.

Panosso, R.; Costa, I.A.S.; Souza, N.R.; Attayde, J.L.; Cunha, S.R.S. \& Gomes, F.C. F. 2007. Cianobactérias e cianotoxinas em reservatórios do estado do Rio Grande do Norte e o potencial controle das florações pela tilápia do Nilo (Oreochromis niloticus). Oecologia Brasiliensis 11: 433-449.

Pressing, M.; Herodek, M.; Vörös, L. \& Kóbor, I. 1996. Nitrogen fixation, ammonium and nitrate uptake during a bloom of Cylindrospermopsis raciborskii in Lake Balaton. Archiv fuer Hydrobiologie 136: 553-562.

Saker, M.L.; Neilan, B.A. \& Griffiths, D.J. 1999. Two morphological forms of Cylindrospermopsis raciborskii (Cyanobacteria) isolated from Solomon Dam, Palm Island, Queensland. Journal of Phycology 35: 599-606.

Saker, M.L. \& Griffiths, D.J. 2001. Occurrence of bloons of the cyanobacterium Cylindrospermopsis raciborskii (Woloszynska) Seenayya and Subba Raju in a north Queensland domestic water supply. Marine and Freshwater Research 52: 907-915.

Shafik, H.M.; Herodek, M.; Pressing, M., Vörös, L. 2001. Factors effecting growth and cell composition of cyanoprokaryote Cylindrospermopsis raciborskii (Wolsz) Seenayya et Subba Raju. Archiv fur Hydrobiologia supplement 140, Algological Studies 103: 75-94.

Strickland, J.D. \& Parsons, T.R. 1965. A manual of sea water analysis. Bulletin of the Fisheries Research Board of Canada 125: 1-185.

Souza, R.C.R.; Carvalho, M.C. \& Truzzi, A.C. 1998. Cylindrospermopsis raciborskii (Wolosz.) Seenaya and a contribution to the knowledge of Rio Pequeno Arm, Billings Reservoir, Brazil. Environmental Toxicology and Water Quality 13: 73-81.

Toledo Jr., A.P.; Talarico, M.; Chinez, S.J. \& Agudo, E.G. 1983. A aplicação de modelos simplificados para a avaliação de processo da eutrofização em lagos e reservatórios tropicais. In Anais do Congresso Brasileiro de Engenharia Sanitária e Ambiental, Camboriú, pp.1-34. (In Portuguese).

Valderrama, G.C. 1981. The simultaneous analysis of total nitrogen and total phosphorus in natural waters. Marine Chemistry 10: 109-122.

von Sperling, E.; Ferreira, A.C.S. \& Gomes, L.N.L. 2008. Comparative eutrophication development in two Brazilian water supply reservoirs with respect to nutrient concentrations and bacteria growth. Desalination 226: 169-174.

Utermöhl, H. 1958. Zur Vervollkommnung der quantitativen PhytoplanktonMethodik. Mitteilungen Internationale Vereiningung fuer Theoretische und Angewandte Limnologie 9: 1-38.

Wilson, K.M.; Schembri, M.A.; Baker, P.D. \& Saint, C.P. 2000. Molecular characterization of toxic cyanobacterium Cylindrospermopsis raciborskii and design of a species-specific PCR. Applied Environmental Microbiology 66: 332-338. 